DOI 10.4467/2543733XSSB.21.022.13815

ANNA CITKOWSKA-KIMLA

Uniwersytet Jagielloński

\title{
Wizje wolności na przestrzeni dziejów. Wolność czlowieka i jej granice. Antologia pojęcia w doktrynach polityczno-prawnych, pod red. O. Góreckiego, t. 1-3, Lódź 2019
}

\author{
Quid est enim libertas? \\ Potestas vivendi ut velis. \\ Paradoksy stoików, V, 1, 34, (46 p.n.e.)
}

\section{Problematyczność pojęcia wolności}

Jednym z najtrudniejszych pojęć w naukach humanistycznych i społecznych jest wolność. To kluczowe dla filozofii pojęcie przysparza badaczom wielu definicyjnych trudności. W klasycznym już dziś ujęciu - Izajasza Berlina - wolność rozpatrywana jest negatywnie jako brak przeszkód w działaniu, brak przymusu oraz niezależność od woli innych. Z kolei pozytywnie może oznaczać możliwość wyboru działania spośród dostępnych rozwiązań, swobodę osiagania wytyczonych przez siebie celów. W tym sensie to poczucie wewnętrznej niezależności, możności decydowania o swoim życiü. Poważne dyskusje toczą się nie tylko wokół problematyki definicji wolności, ale i jej podmiotu, źródła, statusu czy współwystępowania z innymi pojęciami.

$\mathrm{Na}$ te intelektualne wyzwania, stojące przed analizą pojęcia wolności, odpowiada książka Wolność człowieka i jej granice. Antologia pojęcia w doktrynach polityczno-prawnych, wydana przez Wydawnictwo Uniwersytetu Łódzkiego w 2019 roku. Antologia została podzielona na trzy tomy. Pierwszy - jak informują podtytuły - obejmuje okres $O d$ Starożytności do Monteskiusza, drugi - Od Cato’s Letters do klasyków anarchizmu, trzeci - Od Nietzschego do współczesności. Zamierzenie autorów i redaktora tych trzech tomów jest, jak widać, bardzo ambitne. Chodziło bowiem o przybliżenie stanowisk najważniejszych myślicieli wobec problemu wolności na przestrzeni od antyku po czasy obecne.

\footnotetext{
${ }^{1}$ I. Berlin, Dwie koncepcje wolności i inne eseje, przeł. H. Bartosiewicz i in., Warszawa 1991.
} 


\section{Zamysł publikacji}

Pierwszym asumptem do powstania książki była konferencja o wolności w doktrynach społecznych, politycznych i prawnych, która odbyła się w 2013 roku w Uniejowie. Drugą - najważniejszą - inspiracją do jej wydania był brak w Polsce monografii poświęconej rozwojowi pojmowania wolności na przestrzeni dziejów. W tym wypadku od razu należy zaznaczyć, że to najważniejszy atut tej trzytomowej publikacji. Jest nią mianowicie wypełnienie bardzo istotnej luki w polskiej nauce, czego redaktor prowadzący ma świadomość: „Dziwi jednak fakt, że brak jest w polskiej literaturze przedmiotu opracowania, które aspirowałoby do jak najbardziej komplementarnego przedstawienia ewolucji i znaczenia pojęcia wolności, którym operowali przedstawiciele naszego zachodniego kręgu cywilizacyjnego" "Wydaje się, że w tym sensie monografia ta stanie się klasyczna. Trudno będzie bowiem napisać jakikolwiek tekst w szerszej, historycznej perspektywie bez odwoływania się do tej właśnie publikacji. Daje ona wszakże chronologicznie uporządkowany obraz, jak była pojmowana wolność na przestrzeni wieków.

Przemawiającym na rzecz tej książki zabiegiem było opracowanie poszczególnych zagadnień przez najlepszych specjalistów w konkretnej dziedzinie. To ważna zaleta recenzowanej monografii: zaproszono do niej znawców poszczególnych okresów czy myślicieli, aby przybliżyli problematykę wolności w sposób kompleksowy i komplementarny w odniesieniu do dziedziny, w której są ekspertami. Redaktor mówi o tym expresis verbis: „Do napisania zamieszczonych w niej tekstów zostali zaproszeni najwybitniejsi przedstawiciele polskiej nauki specjalizujący się w zakresie omawianej problematyki”3.

Olgierd Górecki skrupulatnie przemyślał konstrukcję monografii. Otwiera ją Wprowadzenie. Stan badań nad kategoriq wolności w literaturze przedmiotu autorstwa redaktora prowadzącego ( $w$ tomie pierwszym). We wstępie thumaczy dylematy związane z eleuterologia, zarysowuje cele przyświecające publikacji, konteksty jej powstania oraz strukturę poszczególnych tomów. Został także przedstawiony aktualny stan badań w polskiej i anglojęzycznej nauce na temat wolności ${ }^{4}$. Wieńczą ją z kolei (w tomie trzecim) rozważania metodologiczne i klasyfikacja pojęcia wolności oraz typologia granic wolności w doktrynach politycznych i prawnych. Oba teksty są autorstwa Olgierda Góreckiego. To bardzo dobry zabieg strukturalny, ponieważ po rozdziałach merytorycznych we wszystkich trzech tomach, które miały charakter eseistyczny, otrzymujemy scalające i podsumowujące rozważania dotyczące klasyfikacji ujęć wolności. Dwa ostatnie rozdziały odbiegają więc od pozostałych, mają jednak swoje głębokie uzasadnienie właśnie jako fragmenty z zakresu metod, definicji i typologii.

Zaletą książki jest pokora przyjętych założeń metodologicznych. Redaktor naukowy wie bowiem, że „Wydaje się wręcz niemożliwe, aby opisać wszelkie ewentualne próby jej [wolności - A.C.-K.] zdefiniowania oraz konteksty, z którymi się konotuje"5. Oddaje jednak do rąk czytelników 62 artykuły poświęcone tej problematyce w historii myśli politycz-

${ }^{2}$ O. Górecki, Wprowadzenie. Stan badań nad kategoria wolności w literaturze przedmiotu, [w:] Wolność człowieka i jej granice. Antologia pojęcia w doktrynach polityczno-prawnych. Od starożytności do Monteskiusza, pod red. O. Góreckiego, t. 1, Łódź 2019, s. 9.

${ }^{3}$ Ibidem, s. 9-10.

${ }^{4}$ Do tego wątku odnoszę się jeszcze w odrębnym akapicie.

${ }^{5}$ Ibidem. 
nej, filozoficznej i społecznej. Pierwszy tom zawiera 17 rozdziałów, drugi 22, a trzeci 23. Widać zatem próbę zachowania symetrii między poszczególnymi tomami, co jest oczywiście ważne przy tworzeniu naukowych publikacji.

Przyjmuję w tej recenzji podobne założenie - nie podejmuję się wyzwania, by odnieść się do wszystkich zamieszczonych w tych trzech tomach tekstów. Można bowiem o każdym rozdziale napisać osobny koreferat. Podejmuję się natomiast zadania, by wskazać jeden, subiektywnie wybrany artykuł z każdego tomu, który - moim zdaniem - wydawał się najbardziej interesujący i godny polecenia.

\section{Trzy rekomendacje}

Z pierwszego tomu wybrałam obszerny rozdział o Paradoksie wolności $w$ filozofii stoickiej autorstwa Janiny Gajdy-Krynickiej - wybitnej znawczyni antycznego kręgu kultury. Tekst bazuje na oryginalnych źródłach, dzięki czemu można rozsmakować się w języku wielkich starożytnych filozofów. Już od pierwszego wersu mamy greckie wtrącenia: „Filozofia stoicka zrodziła się na terenach greckiej oikoumene w epoce określanej mianem hellenistycznej"6. Esej Janiny Gajdy-Krynickiej otwiera rys historyczny, umożliwiający usytuowanie idei stoickich w dziejach epoki hellenistycznej. Można się jednak z niego dowiedzieć, nie tylko o tym, jakie dylematy rodziła w starożytności idea wolności, ale także o takich ciekawych wątkach pobocznych, jak kwestia upadku polis. Do przybliżanego tematu autorka dołącza specjalistyczną literaturę, pozwalającą na dalsze, samodzielne pogłębienie wiedzy na ten temat. Kolejna część rozdziału jest poświęcona pojmowaniu wolności w czasach ateńskiej demokracji. Co ciekawe, wolność funkcjonowała głównie w aspekcie politycznym ${ }^{7}$. Dlatego w tekście mowa jest o „wolności demokratycznej”, której jednym z aspektów była wolność słowa (parrhesia) ${ }^{8}$. Gajda-Krynicka szerzej ujmuje kwestię wolności, rozważając również problem eudajmonologii, co nadaje rozdziałowi ponadczasowy charakter. Aktualność ustaleń, poczynionych przez autorkę, można wykazać przykładowo w pytaniu, czy ,szczęście jest człowiekowi niejako zadane i bynajmniej nie jest tożsame z indywidualnymi odczuciami zadowolenia, radości czy spełnienia" . Dalej dowiadujemy się, że człowiek musi nad swoim szczęściem pracować, co wiąże się z wyrzeczeniami. Pytanie o wolność jest - jak wynika z tego rozdziału - immanentnie powiązane $\mathrm{z}$ fundamentalnymi pytaniami w egzystencji człowieka.

Drugim po okresie hellenistycznym okresem, który przybliża Janina Gajda-Krynicka, jest filozofia Starej Stoi, w której nie mamy już do czynienia z wolnością w aspekcie politycznym. Autorka przyjęła w tym fragmencie Berlinowską klasyfikację wolności w sensie negatywnym (mowa była o tym rozróżnieniu na początku).

Jeszcze inną wizję wolności miała tzw. Stoja Rzymska. Do kluczowych myślicieli tego okresu należą Cyceron, Lucjusz Anneusz Seneka czy Epiktet. Wówczas wolność zaczęła wiązać się także $\mathrm{z}$ pojęciem cnoty.

\footnotetext{
${ }^{6}$ J. Gajda-Krynicka, Paradoks wolności w filozofii stoickiej, [w:] Wolność..., t. 1, s. 67.

${ }^{7}$ Zob. ibidem, s. 69.

${ }^{8}$ Ibidem, s. 71.

${ }^{9}$ Ibidem, s. 75.
} 
Obszerny tekst Janiny Gajdy-Krynickiej zawiera chronologicznie uporządkowane dzieje przekształceń wizji wolności w antyku. Zdecydowanie wykracza poza tytułowe zagadnienie, penetrując różne filozoficzne meandry. Jest napisany - mimo wielu obcojęzycznych wtrąceń - prostym i przystępnym językiem. Prostota pisania o rzeczach abstrakcyjnych w przystępny sposób znamionuje wysoki kunszt pisarski i filozoficzny Janiny Gajdy-Krynickiej.

Z drugiego tomu wybrałam rozdział Ryszarda M. Małajnego Wolność sumienia $i$ wyznania w pogladach ,, The Founding Fathers "10. To klarownie skonstruowany naukowy esej, podzielony śródtytułami na poszczególne części. Otwiera go Tło, w którym autor przedstawia rys historyczny, w punktach ujmując najistotniejsze fakty. Dalej analizuje doktrynę wolności religijnej twórców konstytucji Stanów Zjednoczonych ${ }^{11}$. Interesujące są przemyślenia Małajnego na temat dwóch dróg, jakimi przebiegało wprowadzanie powszechnej wolności religijnej. Z jednej strony, opierało się na koncepcji praw naturalnych, z drugiej na „wskazywaniu na różne przejawy jej naruszenia, będące efektem istnienia Kościoła i religii państwowej" ${ }^{2}$. Małajny poruszył także problem granic wolności sumienia i wyznania, ukazując, jak ważny jest to temat w pismach poświęconych kwestii konfesyjnej omawianych pisarzy politycznych.

To logicznie przeprowadzone dowodzenie wieńczą wnioski, że mimo zgodności poglądów „Ojców Konstytucji” w kwestii konfesyjnej nie byli oni pod tym względem jednolici. Różniły ich przede wszystkim materialne gwarancje wolności oraz praw obywatelskich $^{13}$. Całość najlepiej podsumowuje następująca konkluzja autora: „Doktryna wolności religijnej the Founding Fathers powstała w wyniku konkretnego zapotrzebowania społecznego, na podstawie teoretycznego podkładu racjonalistycznej i deistycznej filozofii, osiagnięć szkoły prawa natury, angielskiego konstytucjonalizmu oraz rodzimych rozwiązań w kwestii wyznaniowej"14.

Trzeci wybrany przeze mnie tekst dotyczy Pojmowania wolności w doktrynie narodowego socjalizmu. Jego autorką jest Maria Zmierczak - wybitna znawczyni problematyki nazizmu i faszyzmu. Rozdział przykuł moją uwagę ze względu na kontrowersyjny tytuł. Jak możliwe jest podjęcie tak paradoksalnie brzmiącego tematu? Autorka rozpoczyna swój tekst właśnie od wątpliwości, które będzie miał każdy po przeczytaniu tytułu tego rozdziału. Expressis verbis wyraziła ten niepokój: ,tak sformułowany temat na pierwszy rzut oka wydaje się nonsensowny, wyrażenie zaś narodowosocjalistyczna wolność brzmi jak oksymoron"15. Kwestia ta zostaje od razu wyjaśniona: ustrój, jaki został historycznie ukształtowany, wykluczał wolność - wolność słowa, sumienia czy wyznania, ale także wolność polityczną wraz z jej przejawami w postaci wolności zrzeszeń, zakładania partii czy wolnych wyborów. Dlatego celem rozważań stała się rekonstrukcja sposobu rozumienia pojęcia wolności przez

\footnotetext{
${ }^{10}$ Niestety, Profesor odszedł, zanim monografia została wydana.

${ }^{11}$ R.M. Małajny, Wolność sumienia $i$ wyznania w pogladach ,, The Founding Fathers”, [w:] Wolność czlowieka i jej granice. Antologia pojęcia $w$ doktrynach polityczno-prawnych. Od „Cato’s Letters” do klasyków anarchizmu, pod red. O. Góreckiego, t. 2, Łódź 2019, s. 141.

${ }^{12}$ Ibidem, s. 146.

${ }^{13}$ Ibidem, s. 154.

${ }^{14}$ Ibidem, s. 155.

${ }^{15}$ M. Zmierczak, Pojmowanie wolności w doktrynie narodowego socjalizmu, [w:] Wolność człowieka i jej granice. Antologia pojęcia $w$ doktrynach polityczno-prawnych. Od Nietzschego do współczesności, pod red. O. Góreckiego, t. 3, Łódź 2019, s. 107.
} 
nazistów. Głównie zaś przez samego Hitlera, ponieważ to on (jako wódz) narzucał rozumienie tego terminu. Za źródła rekonstrukcji poglądów Hitlera na ten temat posłużyły jego wypowiedzi publiczne, a także przemówienia i publikacje innych działaczy NSDAP.

Autorka rozpoczyna rozważania od unaocznienia, jak często niemieckie słowo Freiheit (wolność) pojawiało się w tytułach mów Hitlera. Wyjaśnia przy okazji ważną kwestię rozumienia pod pojęciem „Niemiec” narodu niemieckiego, czyli Volk.

Wśród ważnych konstatacji, ze snutych przez Marię Zmierczak rozważań, warto wymienić taką oto, że „wolność wiązano ze zniesieniem wszelkich międzynarodowych ograniczeń narzuconych przez traktat wersalski"16. Z kolei wolność narodu (Volku) odnosiła się bardziej do bytu zbiorowego niż do państwa ${ }^{17}$. Jej gwarancją miała być siła (dla Hitlera była to nie tylko siła, ale także umiejętność wywalczenia jej sobie). Z kolei siłą niemieckiego narodu miało być zjednoczenie i ta jedność miała stanowić jego siłę ${ }^{18}$. Kluczowe w doktrynie narodowych socjalistów było wierzenie w Niemców oraz w wolność Niemiec ${ }^{19}$.

Maria Zmierczak potwierdza zatem tezę Michaela Hesemana z książki Religia Hitlera, w której wykazał religijne cechy nazizmu, podważając wcześniejsze hipotezy, że narodowy socjalizm był jedynie fenomenem politycznym. Udowodnił, że Hitler i jego współpracownicy wierzyli, iż mają misję Opatrzności, a nazizm był mityczno-religijnym światopoglądem ${ }^{20}$. Chociaż Zmierczak nie przywołuje książki Hesemana, opierając się na tekście Emilia Gentile La religion fasciste, to wyprowadza analogiczne konkluzje: „Pojęcie wolności, polegające na zawierzeniu i całkowitym poddaniu się bóstwu, istotnie jest ważnym elementem każdej religii. W przypadku nazizmu tym bóstwem miał być naród i jego wolność, a Hitler jego uosobieniem"21.

Wybrane przeze mnie trzy rozdziały z trzech tomów monografii o wolności są - w moim przekonaniu - godne rekomendacji, nawet jeśli nie interesujemy się tymi okresami w dziejach myśli politycznej. Łączy je doskonały warsztat badawczy, opieranie się na źródłach pierwotnych w oryginalnych językach oraz ogromna wiedza ich autorów na poruszany temat. Do tego napisane są piękną polszczyzną, w uporządkowany sposób prezentują omawiane zagadnienie i kończą się jednoznacznymi oraz logicznymi wnioskami z przeprowadzonych studiów.

\section{Edytorskie ulatwienia i estetyczne zabiegi}

Cenną edytorską zaletą omawianej monografii jest umieszczanie po każdym z rozdziałów bibliografii. Poszczególne rozdziały stanowią bowiem samodzielne eseje na temat wolności w dorobku konkretnych myślicieli czy danego nurtu. Stąd krótki wybór najważniejszych opracowań omawianego twórcy czy okresu jest bardzo przydatny. Jest to użyteczne zwłaszcza dzisiaj, kiedy na zapytanie w internetowej wyszukiwarce otrzymujemy setki odpowiedzi, które notabene nie są przypadkowo ułożone w danej kolejności. Dzięki pracy poszczególnych

\footnotetext{
${ }^{16}$ Ibidem, s. 109.

${ }^{17}$ Ibidem, s. 110.

${ }^{18}$ Ibidem, s. 113.

${ }^{19}$ Ibidem, s. 116.

${ }^{20}$ Zob. M. Heseman, Religia Hitlera, przeł. A. Walczy, Warszawa 2011.

${ }^{21}$ M. Zmierczak, Pojmowanie..., s. 117.
} 
autorów, którzy ze znawstwem dokonali weryfikacji i podali wybór najważniejszych publikacji na dany temat, czytelnik z łatwością może pogłębić studia nad omawianym zagadnieniem. Ważne, że każdorazowo wskazywane są także najważniejsze obcojęzyczne opracowania wizji wolności w konkretnych okresach i u poszczególnych filozofów.

Drugą bardzo ważną - również edytorską - zaletą jest funkcjonalność przyjętej formy książki. To publikacja, którą czyta się z przyjemnością, ponieważ ma takie cechy jak: przejrzysty $\mathrm{i}$ - co istotne - przestrzennie i z rozmachem rozplanowany układ tekstu na stronach. Co mam na myśli? Ważną dla naukowca przestrzeń do robienia notatek na marginesach. Jak kiedyś ujął to Zygmunt Bauman - do „personalizowania” książek. Nie jest rzeczą dopuszczalną kreślenie po cudzych książkach, jednak własny księgozbiór często ma się opatrzony licznymi przemyśleniami, polemikami, podkreślaniami. Ułatwia to często znalezienie poszukiwanych spostrzeżeń. Publikacja Uniwersytetu Łódzkiego pozwala na przyjemną lekturę, nie tylko ze względu na wymienione wyżej cechy, ale także na czcionkę, która nie wymaga szczególnego rozszyfrowywania. Niestety, coraz częściej niełatwe naukowe teksty wydaje się - chyba ze względów oszczędnościowych - czcionką uniemożliwiającą swobodne czytanie. W przypadku omawianego wydawnictwa jest inaczej - wyraźna duża czcionka, przestrzeń między wierszami i wspomniane marginesy dają duży komfort lektury.

Znakomitym zabiegiem, który bardzo ułatwia orientację w wieloautorskiej monografii, jest opatrzenie każdej strony w nagłówku nazwiskiem autora tekstu (po lewej stronie) i tytułem (po prawej stronie). Przy czytaniu tomów, w których każdy rozdział jest innego autorstwa, to wręcz nieodzowne, by umieścić taką informację. Wspaniale zatem, że nie zapomniano o tak rzadkim obecnie finezyjnym dodatku do publikacji.

$\mathrm{Na}$ osobną uwagę zasługuje przemyślana okładka tych trzech tomów. Pierwsze zdjęcie ukazuje wnętrze starodawnej biblioteki, stosownie do okresu przybliżonego na łamach pierwszego tomu. Drugi tom opatrzono zdjęciem biblioteki o nowocześniejszym charakterze. Trzeci ma na obwolucie nowoczesną bibliotekę - adekwatnie do czasów współczesności, które opisuje. To przemyślany zabieg, który ukazuje, jak skrupulatnie wydano tę monografię.

Ekskluzywności wydaniu dodaje elegancka zakładka w formie przytwierdzonej do oprawy wstążki. Nadaje to książce dawnego uroku pięknie wydawanych woluminów.

Godny podkreślenia jest także przyjęty zabieg techniczny - Noty biograficzne autorów, umieszczone na końcu każdego tomu. To naturalne, zwłaszcza we współczesnym świecie, że chcemy mieć wiedzę o autorze. Na taką potrzebę odpowiedział redaktor, przybliżając sylwetki zaproszonych do współpracy naukowców.

Podsumowując wątek techniczny czy - jak można go również określić - edytorski, pragnę wyraźnie podkreślić, że monografia o wolności jest książką, którą przyjemnie się czyta. To także publikacja, która jest estetycznie satysfakcjonująca.

\section{Uwagi krytyczne}

Przechodząc do krytycznych uwag, zacznę od rzeczy o charakterze technicznym, a następnie omówię merytoryczne.

Należy zauważyć, że książka nie jest wolna od literówek (przykładowo s. 10, wers czwarty). Warto zatrzymać się na tym problemem nie tylko przy okazji recenzowanej 
książki. Niestety, ze smutkiem obserwuję zjawisko upadku sztuki korektorskiej. Przypuszczam, że wiąże się ono $\mathrm{z}$ anonimowością, $\mathrm{z}$ jaką od niedawna mamy do czynienia w wydawaniu książek. W szanowanych wydawnictwach wciąż podaje się imiona i nazwiska korektorów. Są jednak i takie wydawnictwa, które korzystają z usług typu Centrum.Korekty.pl, wówczas nic nie wiemy o osobach poprawiających teksty. Łączy się to z brakiem jednoznacznej odpowiedzialności za wykonanie korekty. Niestety, książki po takiej anonimowej korekcie są pełne błędów (czasem bardzo oczywistych), co pogarsza jakość czytania. Jeśli do znajdowania błędów trzeba mieć wiedzę z zakresu nauki o języku, to jednak do wyłapywania literówek wystarczy uważne czytanie. W omawianej książce nie mamy do czynienia z przytłaczającą liczbą błędów, przeciwnie, generalnie jest to tekst dobrze przygotowany i staranny.

Wielka szkoda, że przy tego typu przekrojowej publikacji nie sporządzono indeksu nazwisk. Wydaje się to wręcz nieodzowne, aby taki indeks był na końcu każdego tomu. Jak inaczej można wydobyć informacje o konkretnym myślicielu jakiegoś nurtu, jeśli nie mamy indeksu nazwisk? To jest niestety bolączka wielu wydawnictw naukowych, które - w moim przekonaniu - powinny być obligowane do trzymania standardów i ułatwiania prowadzenia badań przez umieszczanie indeksów nazwisk. Oczywiście do lamusa odszedł już zwyczaj umieszczania indeksu rzeczowego, którego młody czytelnik zapewne by nawet nie poszukiwał, bo obecnie już nie wydaje się książek nim opatrzonych.

Sui generis mankamentem książki jest różny styl omawianych zagadnień, a co się z tym wiąże - różny stopień trudności w zrozumieniu niektórych tekstów. Wynika to oczywiście z indywidualnych zdolności poszczególnych autorów do jasnego i klarownego pisania czasem o rzeczach bardzo trudnych, a czasem odwrotnie - o prostych rzeczach pisze się tak zawile, że wydają się bardzo skomplikowane. Fakt ten usprawiedliwia Olgierd Górecki. Tłumaczy bowiem, że każdy tekst ,,przybiera odmienną i wyjątkową formę"22.

Przechodząc do zawartości książki, pragnę wskazać, że jej mankamentem merytorycznym jest przyjęcie anglojęzycznej perspektywy badań. Widać to już we Wprowadzeniu, w którym Redaktor przybliżył stan badań nad zagadnieniem wolności tylko na gruncie polskim i angielskim (chociaż tytuł tego nie zapowiada). Szkoda, ponieważ problem wolności poruszono na gruncie filozofii różnych obszarów językowych, w tym niemieckim, francuskim, hiszpańskim czy rosyjskim. Warto więc było dodać także stan badań z wspomnianych obszarów. Teksty z tych kręgów kulturowych nie są przygotowane symetrycznie. Najwięcej jest oczywiście omówionych wizji wolności w dorobku anglojęzycznych myślicieli. Dużo jest także niemieckojęzycznych. Zaczęto je przybliżać od reformacji przez Kanta, Hegla, Marksa, Engelsa, przez rewolucyjnych konserwatystów, nazizm po Nową Lewicę. Podobnie wiele miejsca poświęcono francuskojęzycznym myślicielom. Nie ma jednak omówienia stanu badań nad wolnością w tych krajach, co postrzegam jako poważny i niewytłumaczony przez Redaktora mankament. Warto było zaprosić znawców Francji, Niemiec czy Rosji, aby wskazali kluczowe dla badań w tych państwach opracowania i nazwiska naukowców. Warto było wprowadzić te wątki do Wprowadzenia, aby były koherentne z zawartością monografii.

W książce brakuje rozdziałów poświęconych filozofii egzystencjalnej, co wydaje mi się poważnym niedociągnięciem, biorąc pod uwagę istotę rozważań francuskich filozofów

\footnotetext{
${ }^{22}$ O. Górecki, Wprowadzenie..., s. 11.
} 
tego nurtu nad problemem wolności. Szkoda ponadto, że nie uwzględniono słynnej Ucieczki od wolności Ericha Fromma. Brakuje także antropologicznego ujęcia kwestii wolności na styku myśli psychologicznej, filozoficznej czy społecznej i politycznej, które pokazywałoby wieloznaczność tego pojęcia.

Niedosyt pozostawia brak omówienia idei wolności u włoskich myślicieli. Jest oczywiście rozdział poświęcony Niccolò Machiavellemu, nie ma jednak postaci z innych okresów. Są natomiast dwa teksty, które obejmują prawie ten sam czas w Niemczech (Marka Maciejewskiego i Marii Zmierczak). Szkoda, że nie przyglądnięto się Włochom, kiedy kształtował się faszyzm.

Kolejna rzecz to bardzo wyrywkowo potraktowane stanowisko myśli rosyjskiej wobec problemu wolności. Brakuje nie tylko ważnych nazwisk myślicieli z tego obszaru (przykładowo Aleksandra Hercena, Fiodora Dostojewskiego, Lwa Tołstoja, Gieorgija Plechanowa czy Nikołaja Bierdiajewa), ale także specjalistów w tej dyscyplinie (chociażby Krystyny Chojnickiej czy Michała Bohuna).

Konkludując podjęte rozważania, pragnę wyraźnie podkreślić, że mimo wyłuszczonych uwag o charakterze krytycznym przeważają uwagi o charakterze pozytywnym. Książka Wolność człowieka i jej granice jest ważna i wypełnia istotną lukę w polskich badaniach nad tym zagadnieniem. Nie waham się powiedzieć, że stanowi kompendium wiedzy na ten temat, przygotowane przez wyróżniających się polskich badaczy. Jest ponadto starannie wydana, z estetycznym rozmachem i elegancją, których brakuje wielu współczesnym naukowym publikacjom.

Anna Citkowska-Kimla (ur. 1973), dr hab., prof. UJ - studia politologiczne, polonistyczne i filozoficzne ukończyła na Uniwersytecie Jagiellońskim; pracuje w Instytucie Nauk Politycznych i Stosunków Międzynarodowych UJ; gościnny wykładowca Uniwersytetu Wiedeńskiego, stypendystka Goethe-Stipendium Uniwersytetu im. F. Schillera w Jenie. Zajmuje się myślą polityczną (zwłaszcza niemiecką), polską sceną polityczną oraz współczesnymi doktrynami i ruchami politycznymi.

Autorka książek, artykułów naukowych publikowanych w czasopismach krajowych i zagranicznych oraz w pracach zbiorowych. Wydała między innymi: Państwo, religia, historia. Myśl polityczna Friedricha von Hardenberga (Novalisa), Kraków 2006; Romantyzm polityczny w Niemczech. Reprezentanci, idee, model, Kraków 2010; Politische Ideen deutschsprachiger Denker im 20. Jahrhundert. Von Karl Jaspers bis Golo Mann, Kraków 2018. 